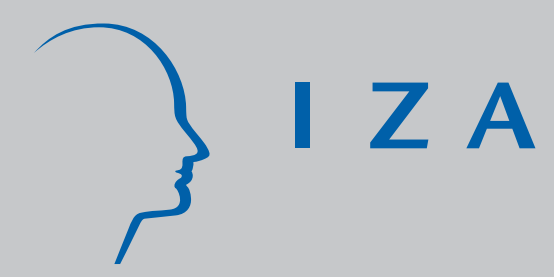

IZADP No. 2969

Occupational Choice of High Skilled Immigrants in the United States

Barry R. Chiswick

Sarinda Taengnoi

August 2007 


\title{
Occupational Choice of High Skilled Immigrants in the United States
}

\author{
Barry R. Chiswick \\ University of Illinois at Chicago \\ and IZA \\ Sarinda Taengnoi \\ Western New England College
}

Discussion Paper No. 2969

August 2007

IZA

P.O. Box 7240

53072 Bonn

Germany

Phone: +49-228-3894-0

Fax: +49-228-3894-180

E-mail: iza@iza.org

\begin{abstract}
Any opinions expressed here are those of the author(s) and not those of the institute. Research disseminated by IZA may include views on policy, but the institute itself takes no institutional policy positions.

The Institute for the Study of Labor (IZA) in Bonn is a local and virtual international research center and a place of communication between science, politics and business. IZA is an independent nonprofit company supported by Deutsche Post World Net. The center is associated with the University of Bonn and offers a stimulating research environment through its research networks, research support, and visitors and doctoral programs. IZA engages in (i) original and internationally competitive research in all fields of labor economics, (ii) development of policy concepts, and (iii) dissemination of research results and concepts to the interested public.
\end{abstract}

IZA Discussion Papers often represent preliminary work and are circulated to encourage discussion. Citation of such a paper should account for its provisional character. A revised version may be available directly from the author. 
IZA Discussion Paper No. 2969

August 2007

\section{ABSTRACT}

\section{Occupational Choice of High Skilled Immigrants in the United States ${ }^{*}$}

This paper explores the impact of English language proficiency and country of origin on the occupational choice of high-skilled immigrants in the U.S. using the 2000 Census. The findings reveal that high-skilled immigrants with limited proficiency in English, or whose mother tongue is linguistically distant from English, are more likely to be in occupations in which English communication skills are not very important, such as computer and engineering occupations. Moreover, the degree of exposure to English prior to immigration is found to have little influence on selecting occupations in the U.S. The paper also shows that immigrants from some origins with little exposure to English and whose native language is far from English tend to be in some "speaking-intensive" occupations, in particular social services occupations. These occupations may not require workers to be fluent in English if they mostly provide services to immigrants from their same linguistic background.

JEL Classification: J15, J24, J61

Keywords: $\quad$ immigrants, English proficiency, occupation, high-skilled workers

Corresponding author:

Barry R. Chiswick

Department of Economics

University of Illinois at Chicago

601 South Morgan Street

Chicago, IL 60607-7121

USA

E-mail: brchis@uic.edu 
Revised July 2007

\section{Occupational Choice of High Skilled Immigrants in the United States}

In recent decades, many developed countries have adopted immigration policies to attract high-skilled foreign workers. The international competition for skilled workers is largely due to skill-biased technological change, population aging, and globalization (Kapur and McHale, 2005). In the U.S. economy, several sectors have relied on a large number of high-skilled immigrants, especially in science and engineering (National Science Board, 2003). The demand for high-skilled immigrants will continue as the computer based technology revolution and globalization appear to put a premium on these skills. Understanding the occupational patterns of skilled immigrants is important since it would allow policy makers and employers to create the appropriate incentives that can attract these immigrant workers.

This paper analyzes the occupational choice of high-skilled adult (age 25 to 64) male immigrants, defined as those who received at least a college degree and work in professional and managerial occupations in the U.S. labor market. ${ }^{1}$ The emphasis is on the impact of English proficiency and country of origin on immigrants' occupational choice. The models are tested using the 2000 U.S. Census and the Occupational Information Network ( $\left.\mathrm{O}^{*} \mathrm{NET}\right)$ database on occupational skills requirements. Among other findings, the results show that immigrants whose mother tongue is linguistically further from English are more likely to be in occupations in which communication in English is not very

important, such as computer and engineering occupations. The degree of exposure to 
English prior to immigration does not seem to have a strong influence in selecting occupations in the U.S.

Section I discusses proficiency in English and occupational choice. Section II discusses the data to be studied, language proficiency and occupations among high-skilled immigrants in the 2000 U.S. Census. The empirical framework and analysis of the determinants of occupational attainment are presented in sections III and IV, respectively, while the conclusion is in section $\mathrm{V}$.

\section{PROFICIENCY IN ENGLISH AND OCCUPATIONAL CHOICE}

It has been documented in many immigration studies that proficiency in the destination language is one of the most important determinants of immigrants' economic success. Those who are fluent in the destination language earn more than those who are not, other things being the same (Chiswick and Miller, 1995; Kossoudji, 1988).

Proficiency in the destination language varies across individuals; and it is determined by many factors (Chiswick and Miller 1992, 1995, 1998). Chiswick and Miller (1995) suggest that immigrant's fluency in the destination language is a function of economic incentives, exposure to the destination language, and efficiency in language acquisition. "Economic incentives" are factors related to increased employment and wage rates due to greater proficiency, and the length of the expected future duration in the destination (Chiswick and Miller 1995 and 1998; Dustmann 1999).

"Exposure” refers to the extent to which immigrants are exposed to the destination language before and after migration. The pre-migration exposure involves immigrants' country of origin: whether the language used in the country, or the language taught in 
school, is the same as the destination language. In case of the U.S, the pre-migration exposure to English is maximized for immigrants from English-speaking countries. The post-migration exposure depends on time spent in the destination, location of residence (e.g., residing in an ethnic enclave), and marriage (whether an immigrant is married to a native speaker), among other factors. Generally, fluency in the destination language increases with exposure, that is, the longer the duration of residence, and living in an environment in which few people communicate in the immigrant's mother tongue (Chiswick and Miller 1995 and 1998; Carliner 1995 and 2000).

"Efficiency" refers to the ability to convert exposure and economic incentives into language skills. It is influenced by certain immigrant characteristics, such as age at arrival and education. Learning a new language is expected to be easier for those who migrate at a young age and for those who have a higher level of education (Chiswick and Miller 1995 and 1998; Long 1990). Those whose mother tongues are linguistically close to English, for example, French, will be more efficient in learning English than, say, Korean speakers.

The importance of English skills varies across occupations. For example, speaking skills are more important for "lawyers" and "teachers" than for "biological scientists" and "engineers". English speaking ability could therefore be one of the determinants of the occupational choice of immigrants. For example, Kossoudji (1988) finds that Asian immigrants who are not fluent in English are less likely to work in sales occupations in which speaking skills are very important. Berman et al. (2000) study the growth of Soviet immigrants' earnings in Israel. They show that being fluent in Hebrew has no effect on wage growth in low-skilled occupations, but significantly contribute to a wage growth for high-skilled occupations. In the U.S., varying degrees of using English communication 
skills across occupations, and thereby a possibly different wage premium associated with fluency in English, could be one of the factors that immigrants take into account when choosing an occupation.

The primary hypothesis to be tested is that among high-skilled immigrants in the U.S., those with a lower degree of proficiency in English are less likely to be employed in occupations that require greater use of English language skills.

\section{THE DATA}

The primary data set for this study is the 2000 U.S. Census, 5\% Public Use Microdata Sample (PUMS). Male immigrants aged 25 to 64 who are not enrolled in school at the time of the census, are employed, and worked in the year prior to the census are included in the study. High-skilled immigrants are defined in this study as those who were not born in the U.S, received at least a college degree (16 years of schooling or more) and work in management, professional and related occupations based on Census 2000 occupational classifications. These occupations are (1) Management, (2) Business (including financial operations), (3) Computer (including mathematical science), (4) Engineering (including architecture), (5) Sciences (life, physical, and social science), (6) Social services, (7) Law, (8) Education (including training and library), (9) Entertainment (arts, designs, sports and media), and (10) Healthcare.

The Census data provide useful information on the immigrants' demographic and economic characteristics, as well as English speaking ability. One limitation, as mentioned by Jasso et al. (2000), is a lack of information regarding the visa status of the foreign-born workers (i.e., whether a foreign-born person is admitted through a family-based visa, an 
occupational-based visa, or on a temporary non-immigrant work visa), although naturalized citizens can be identified. Therefore, besides legal immigrants, the sample in this study includes the foreign-born who are illegal aliens and legal non-immigrants (e.g., holders of H-1B visas). While there would be very few illegal aliens among those working in highskilled occupations. A significant but unknown portion of recent arrivals in the sample are legal residents on temporary work visas.

The Occupational Information Network $\left(\mathrm{O}^{*} \mathrm{NET}\right)$ database is also used in the analysis. The O*NET database was developed by the U.S. Department of Labor to replace the Dictionary of Occupational Titles (DOT) as a source for occupational information. Unlike DOT which was published in print and focused on blue-collar workers, the O*NET is available electronically providing more flexibility for users. It also takes into consideration current labor market conditions by allowing multiple skills to be required of workers in any given occupation (Mariani 1999). The database used in this study is version 5.1, which was released in November 2003, and it has the coding system based on the 2000 SOC. Since the occupations included in the 2000 Census data are also expressed in the SOC coding system, the merging of the 2000 Census and the 5.1 O*NET is straightforward.

Based on the National Center for O*NET development, the information on the $\mathrm{O}$ *NET database comes from a collection of surveys completed by people working in various occupations; and it is organized by different levels of description. For the purpose of this study, variables in the "Worker requirements" category are used. The selected variables from this category are (1) writing skill: communicating effectively in writing as appropriate for the needs of the audience, (2) speaking skill: talking to others to convey 
information effectively, (3) mathematics skill: using mathematics to solve problems, and (4) science skill: using scientific rules and methods to solve problems.

The four basic skills were scored from 1 to 5 , where 5 indicates that such a skill is very important for performing tasks in a specified occupation. For example, civil engineers have the score of 3.96 for writing, 3.66 for speaking, 4.81 for mathematics, and 4.44 for science. Therefore, we can conclude that speaking and writing are less important for civil engineers than mathematics and science skills. Psychologists have the score of 4.8 for writing, 4.4 for speaking, 4.4 for mathematics and 4.0 for science, indicating that all basic skills are, in general, important. In short, the use of O*NET in this study serves as a guideline to indicate whether communication in English is very important to perform tasks in a specified occupation. ${ }^{2}$ There are 148 occupations in the ten professional specialty categories indicated above included in the study (See Appendix A for the O*NET data by occupation).

\section{EMPIRICAL FRAMEWORK}

In attempting to test whether English proficiency and country of origin have an impact on high-skilled immigrants' occupational choice; a multinomial logit analysis is used. The dependent variable in the analysis is "occupation", which is a variable with 10 categories: management, business, computer, engineering, sciences, social services, law, education, entertainment, and healthcare. Of all occupational categories, "healthcare” is the most homogenous group both in terms of skills required to perform tasks and demographic characteristics; it is therefore used as a reference group.

Occupation is, by definition, a categorical variable, and these categories are mutually exclusive, but occupation can not readily be ordered. Occupational rankings and 
prestige scores have been created, but these tend to be based on the average level of schooling or earnings in the occupation. Multinomial logit analysis appears to be the best statistical methodology for analyzing occupational choice across the broad high skilled occupations studied here.

For independent variables, the model includes some demographic variables that are often included in the study of immigrant labor market outcomes: years of schooling, age at migration, years since migration and its square, a dichotomous variable indicating whether an immigrant is married with a spouse present, a dichotomous variable indicating whether an immigrant is a citizen through naturalization, and a set of country-of-origin dichotomous variables.

The Census asked the respondents if they speak a language other than English at home, and if so, to identify that language and to report how well they speak English. Thus there are five English speaking categories: speak only English, or speak another language and speak English very well, well, not well, and not at all. A dichotomous variable for a high level of English fluency is created; it is set to one for immigrants who report their English ability as "speak only English" or speak "very well”; and set to zero for those who speak "well”, "not well" or "not at all". Table 1 reveals that only $0.2 \%$ of high-skilled male immigrants in the sample identified themselves as not being able to speak English at all, while another $2.3 \%$ did not speak English well. Putting the "well" category into the proficient group would therefore leave very few high-skilled immigrants as not proficient.

[Insert Table 1 about here]

Since the contribution of English language skills to the productivity of workers varies by occupation, an increase in the earnings associated with being fluent in English is 
therefore likely to be greater for some occupations and less so for others. Immigrants with a high level of proficiency in English would then be more likely to select occupations, and be selected by employers for occupations, that require a more intensive use of English. Those who do have this high level of proficiency, on the other hand, would tend to be in occupations in which communication in English is less important.

Finally, fifteen country-of-origin dichotomous variables are created: (1) EnglishSpeaking Developed countries (ESDC) includes U.K., Ireland, Canada, Australia, and New Zealand, and is used as a reference group, (2) Eastern Europe and former Soviet Union, (3) Other Europe, (4) Mexico, (5) Cuba, (6) Other countries in the Americas, (7) China, includes Taiwan and Hong Kong, (8) Korea, (9) Japan, (10) the Philippines, (11) Indochina, includes Laos, Vietnam and Cambodia, (12) South Asia, (13) Other Asia and islands in the Oceania region, (14) Africa, and (15) the Middle East.

The dichotomous variables for origin not only capture the effects of country of origin differences in the level of English fluency of immigrants, as stated earlier, but also possibly reflect other unmeasured country-specific characteristics. It is expected that immigrants from origins with minimal exposure to English before immigration would experience a more difficult time in learning and communicating in English. They would, therefore, tend to select occupations in which English skills are not very important.

\section{EMPIRICAL ANALYSIS}

Table 2 reports the means and standard deviations of the variables used in the analysis. The average schooling attainment of male high-skilled immigrants in the U.S. in 2000 is 17.4 years. Since the age at migration of this immigrant group is, on average, 23 
years, it can be inferred that most of skilled immigrants' education was obtained in the country of origin. The mean duration of residence in the U.S. is about 19 years. On average, 83\% of male high-skilled immigrants report they speak English fluently (speak only English or speak it very well), and 53\% are U.S. citizens by naturalization. The major source regions are South Asia (16\%), English-speaking developed countries (12\%), Europe, excluding ESDC and Eastern Europe (11.4\%), and China (11.1\%). Of all professional occupations, $25 \%$ of high-skilled immigrants work in management- related occupations, followed by $18 \%$ in computer, $14 \%$ in engineering, and $12 \%$ in healthcare occupations.

[Insert Table 2 about here]

The O*NET data indicate that some skills may be more important than others within occupations. Table 3 reveals that speaking skills are generally important in all professional occupations, especially in management, social services, law, education, and healthcare. Writing skills are particularly important in law and sciences. Computer, engineering, and sciences are occupations in which mathematics skills are used intensively. Lastly, science skills are very important in performing tasks in engineering, sciences and healthcare.

[Insert Table 3 about here]

Table 4 reveals that immigrants from English-speaking developed countries and Europe (excluding Eastern Europe) are major groups working in all high-skilled occupations, with the exception of computer, engineering, and healthcare fields. Over $30 \%$ of male high-skilled immigrants in healthcare fields are from South Asia and the Philippines. Chinese and South Asian immigrants account for $47 \%$ in computers and $30 \%$ 
in engineering. Of those in the entertainment occupations, $42 \%$ are from the English speaking developed countries and Europe.

\section{[Insert Table 4 about here]}

Table 5 reports the estimated multinomial logit coefficients of the explanatory variables on the log-odds of working in a specified professional occupation relative to working in the benchmark, a healthcare occupation. A positive (negative) coefficient means that, the independent variable increases (reduces) the probability of a high-skilled immigrant working in the specified occupation, as compared to healthcare.

Although the multinomial logit model intuitively seems to be an appropriate methodology for the analysis of occupational choice of high-skilled immigrants, the Independence of Irrelevant Alternatives - IIA property (i.e., the odds ratios of choosing existing alternatives are assumed to be independent of the other alternatives.) is tested by using McFadden-Train-Tye (1981) likelihood ratio statistic. The test statistic is calculated by 2[the maximized log likelihood value of unrestricted model - the maximized log likelihood value of restricted model]. It is an asymptotic chi-square distribution with degrees of freedom equal to the number of parameters in the restricted model. The test indicates that the multinomial logit model does not violate the IIA.

An increase in the years of schooling (Table 5) lowers the odds of an immigrant working in all occupations, except law-based and sciences, relative to healthcare. ${ }^{3}$ With an increase in duration in the U.S., there is a greater probability for high-skilled immigrants to work in social services and education occupations relative to healthcare, and the likelihood tends to increase among those who immigrated earlier. 
It is apparent that the age at migration significantly determines the occupations of immigrants. With the exception of computer, sciences, and law-related occupations, the older an immigrant at the time of arrival, the more likely he works in all other occupations rather than healthcare, other things the same. Male immigrants who are not married are more likely to be in social services, education, law-related, and entertainment. Relative to other occupations, except law-related ones, immigrants who are naturalized U.S. citizens have a greater likelihood of being in healthcare occupations. With an exception of law, business, and education, greater fluency in English means the man is more likely to work in healthcare than in other occupations. Greater proficiency in English increases the probability of being in a law related occupation than in healthcare.

The findings of the higher odds of being in healthcare occupations rather than many other occupations among high-skilled male immigrants could be due to the growing demand for healthcare professions to serve the increasing aged population of the U.S. A shortage of nurses has led to the issuing of up to 50,000 visas for foreign nurses in 2005, most of whom were female. (Fong 2005). For immigrant physicians, in addition to H-1B visas, the visa that most skilled temporary workers hold, they can also work on the J-1visas in health professional shortage areas. ${ }^{4}$

[Insert Table 5 about here]

There could be a problem of causality from using the current English fluency variable to predict the current occupation of immigrants. English fluency in the Census is measured at the time of the interview, but immigrants could have chosen their occupations much earlier. It is also possible that occupations could have an impact on immigrants' English fluency. Working in English speaking-intensive occupations, for example, could 
help to improve immigrants’ English-speaking ability. To adjust for the potential causality problem, the dichotomous variable for English fluency is replaced by a variable that is clearly exogenous to occupation, the "linguistic distance" of the immigrant's origin language from English.

One way to measure the linguistic distance from English is to know how difficult it is for English-speaking natives to learn new languages. ${ }^{5}$ The U.S. Department of State, School of Language Studies teaches a variety of languages to English-speaking Americans. After 16 to 24 weeks of instruction, the achievement in speaking foreign languages is then measured. A lower score implies that it is more difficult for English-speaking Americans to learn that language and thus implies a greater linguistic distance from English (Chiswick and Miller 2005). Appendix B shows the language scores and linguistic distances of foreign languages reported in the U.S. Census. The score of 1.00 for Korean and of 3.00 for Swedish, suggests that Korean is more difficult to learn, and thus a greater linguistic distance from English than Swedish. The value of linguistic distance is assigned to be equal to 1 divided by the language score, so that a higher value implies a greater linguistic distance.

The 2000 Census asked respondents who indicated that they speak a language other than English at home to identify the language. It is reasonable to assume that, for a foreign-born person, the language other than English spoken at home would be his mother tongue. The linguistic distance is then assigned for the foreign language reported. For foreign-born persons who reported they speak only English, this study uses the value of the linguistic distance for the language that is most often spoken by immigrants born in the same country. If there are two languages spoken by an approximately equal proportion of 
immigrants from that country, the linguistic distance is computed as the average of the linguistic distance of the two languages. For immigrants from English-speaking countries, the linguistic distance score of 0 is assigned. ${ }^{6}$

The results in Table 6 reveal that the more linguistically distant from English is the immigrant's mother tongue, the more likely he is to be employed in computer, engineering, and science occupations rather than healthcare. On the other hand, the magnitude of estimated coefficients for the linguistic distance across occupations suggest that the closer to English is the immigrant's mother tongue, the more likely he is to be in education and law-related occupations, followed by entertainment, social services, business, management, and healthcare. In other words, immigrants whose mother tongue is more distant from English are more likely to be in occupations in which English communication is not very important. The signs and magnitudes of the estimated coefficients of all other explanatory variables in Table 6 are generally similar to those in Table 5.

[Insert Table 6 about here]

It is worth noting that the patterns of findings remain the same using an OLS analysis with the dependent variable defined as the narrowly defined occupation O*NET scores on requirements for English communication skills in both speaking and writing, (Table 7). As would be expected, adult male immigrants with a higher level of schooling, who have been in the U.S. a longer period of time and whose mother tongue is linguistically closer to English are more likely to be in occupations requiring greater proficiency in speaking and writing English.

Surprisingly, those who immigrated at older age, and presumably had more of their schooling prior to immigrating, are also more likely to be in occupations requiring greater 
English language proficiency. In spite of the minimal English language proficiency requirement for citizenship, naturalized citizens are less likely than other male immigrants in high-skilled jobs to be in occupations requiring greater English language proficiency. There maybe a tradeoff in the labor market between English proficiency and U.S. citizenship.

\section{[Insert Table 7 about here]}

The level of exposure to English prior to immigration varies across origins, as well as do other relevant unmeasured variables. Table 8 presents a model with a set of countryof-origin dichotomous variables, to control for unmeasured country-specific characteristics. Immigrants from English-speaking developed countries are used as the reference group. Since the linguistic distance from English variable is created based on country of origin, the exclusion of this variable from the equation is necessary in order to avoid a collinearity problem.

\section{[Insert Table 8 about here]}

The results reveal a higher likelihood for Eastern European immigrants to select occupations in computer, engineering, sciences, and entertainment relative to healthcare, other things the same. On the other hand, high-skilled immigrants from other parts of Europe prefer all other occupations, except social services and law, to healthcare relative to ESDC immigrants. Mexican immigrants are more likely to be in social services and education, but less likely to be in all other occupations relative to healthcare.

There are two hypotheses as to why high-skilled Mexican immigrants would be more likely to work in occupations in which speaking English is very important. First, the Spanish language is quite close to English (see Appendix B). High-skilled immigrants from 
Mexico might then be expected to learn English quickly. Second, Mexico is the largest sending country of immigrants to the U.S. and many other immigrants come from the Spanish-speaking countries in the rest of Latin America. These immigrants tend to be very low skilled with poor English language skills. As a result, the ratio of high-skilled to lowskilled immigrants from Spanish-speaking origins is quite low. It is quite common to observe the use of the Spanish language in many schools and social services centers. Having bilingual English-Spanish skills may be of value in these educational and social service occupations.

The results do not reveal a clear occupational pattern among Asian immigrants. Immigrants from Japan are less likely to work in the computer sector relative to healthcare, but are more likely to work in management, business, engineering, sciences, and education. The only occupation that Korean high-skilled immigrants favor over healthcare is social services.

Japan is the world's second largest economy and a major trading partner with the U.S. Many U.S. firms do business in Japan, and many Japanese firms also have subsidiaries based in the U.S. Japanese high-skilled workers may therefore have good opportunities to work in management, business, and science-based sectors in the U.S. labor market. ${ }^{7}$ Furthermore, there has been a high demand in the U.S. to learn the Japanese language and culture. According to the Japan Foundation, in 2004 there were 645 secondary schools and more than 500 universities in the U.S. that offer Japanese language classes. This could be partially responsible for the greater likelihood among Japanese immigrants to work in teaching rather than healthcare occupations, other things the same. 
The findings reveal the higher odds of being in business, computer, engineering, and the sciences than in healthcare among immigrants from China, while being from Indochina increases the likelihood of working in computer and engineering. These are occupations in which English communication skills are not very important.

Public policies both in the U.S. and the origin could certainly have an impact on immigrants' occupations in the U.S. Many healthcare professionals in the U.S. are from the Philippines as a result of a shortage of this profession in the U.S. coupled with an encouragement from the Philippines government for workers to train for these occupations with the expectation of emigrating (Kapur and McHale, 2005).

As a former British colony, many South Asian immigrants have greater exposure to English prior to immigration, and therefore possibly better English communication skills than those from elsewhere. The findings show that, with an exception of the computer field, high-skilled South Asian male immigrants are more likely to work in healthcare than in other occupations. The occupational pattern of immigrants from South Asia is not different from those from other parts of Asia (except Japan, Korea, and China) that do not have as much exposure to English before immigration. Healthcare is preferable to any other occupation, except social services, among immigrants from Africa. Lastly, the probability that an immigrant from the Middle East works in healthcare is higher than other occupations, with an exception of engineering, other things the same.

The multinomial logit model controlling for both English fluency and a set of country-of-origin dichotomous variables was also tested, despite the potential endogeneity of using current fluency in English to predict the current occupations of immigrants. The results (available on request) show that, compared to the model reported in Table 5 when 
country-of-origin variables are not controlled for, the estimated coefficients of the English fluency variable are smaller in magnitude, but remain significant at the $5 \%$ level for all occupations except management and business.

In summary, of all ten occupational categories, computer and engineering are occupations in which immigrants from Eastern Europe, China, Indochina, South Asia, other Asia, and Middle East are most likely to work. Immigrants from Mexico and other countries in Latin America (except Cuba), Korea and Africa are most likely to work in social services occupations. Healthcare is the most favored among immigrants from the Philippines and Cuba, while those from European countries (except Eastern Europe) prefer management and business occupations.

\section{CONCLUSION AND POLICY SUGGESTION}

This paper analyzes the determinants of occupational choice, with an emphasis on English proficiency and country of origin, among male high-skilled immigrants in the U.S. labor market, using the 2000 U.S. Census and the Occupational Information Network (O*NET) database on occupational skill requirements. It is reasonable to expect that highskilled immigrants in the U.S. with a lower degree of English language proficiency are less likely to be employed in occupations that require more communication in English. The findings reveal that, in general, high-skilled immigrants with proficiency in English have a greater likelihood to be in occupations in which speaking skills are very important, other things the same. Because of the possible endogeneity from using current English language skills in the analysis, a measure of the linguistic distance from English of the immigrants' mother tongue is also employed. The findings show that immigrants whose native 
language is further away from English linguistically are more likely to be in occupations in which communication in English is not as important, in particular computer and engineering occupations.

Interestingly, exposure to English in the origin country prior to immigration does not necessarily lead immigrants to select occupations that highly value English language skills. Furthermore, some occupations in which communication skills are very important, such as social services, may not require workers to be fluent in English if they mostly provide services to immigrants from their same linguistic background. This may explain why immigrants from some origins with little exposure to English and whose native language is far from English tend to be in some "speaking-intensive" occupations, in particular social services.

Lastly, immigration policy and labor market conditions in both the U.S. and the origin may also lead immigrants to select one occupation over another in the U.S. For example, knowing of the high demand in the computer industry and the ease of obtaining a visa to work in this industry could lead some foreign students who plan to migrate to the U.S. to select computers as their field of study, and hence their occupations.

The National Science Foundation (NSF) projects that between 1998 and 2008, the employment in science and engineering fields will grow by more than 50 percent (Committee on Equal Opportunities on Science and Engineering, 2000). Given the low enrollment of those born in the U.S. in these fields, the reliance on high-skilled foreign workers is likely to continue. Yet a tightened visa policy following the September 11, 2001 tragedy makes it more difficult for students in many countries to enter the U.S. According to the NSF, the enrollment of foreign graduate students in science and engineering 
programs dropped by 20\% from 2001 to 2006 (NSF, 2006). In addition, the number of H1B visas issued for temporary high-skilled workers in the U.S. has been drastically reduced, from 195,000 in 2000 to 65,000 per year since fiscal year 2004. To maintain and strengthen the U.S. competitiveness in the world economy and to fill in the imbalance of supply and demand in certain occupations, the U.S. immigration policy needs to be more open to skilled foreign workers. One way is to attract foreign students, especially in fields that are in high demand, by making it easier for them to obtain student visas and then permanent resident visas. 


\section{NOTES}

1. The analysis is limited to adult but not aged males because of the complexity of analyzing the connection between occupational choice and labor supply decision of aged males and females.

2. The $\mathrm{O}^{*} \mathrm{NET}$ data on occupational language requirements were also used in Chiswick and Miller (2007) to study immigrant earnings. The data can be accessed at http://www.onetcenter.org

3. The data on the specific educational qualifications (e.g field of study) as well as the foreign schooling are not available. We, however, follow the Chiswick (1978) and Betts and Loftstrom (1998) approach, to obtain the estimated years of foreign education as follows "Assuming individuals are in school continuously from age six, if an immigrant migrated at age 6 or younger, then all schooling took place in the U.S. If the age at migration was between six and the total number of years of schooling plus six, premigration education is set at age at migration minus six and the remainder is assumed to be U.S. education. If age at migration is greater than the years of schooling plus six, it is assumed that all schooling took place abroad." When foreign and U.S. years of schooling are used as explanatory variables, the signs and magnitudes of the estimated coefficients of both variables are similar for all occupational categories. The results suggest that the odds of being in a certain occupation do not vary with the source of education, other things the same. For this reason, total years of schooling is employed as an explanatory variable in the analysis. Furthermore, due to the small range of the schooling variable in high-skilled occupations, a quadratic specification of the schooling variable can not be used.

4. H-1B visa category allows high-skilled non-immigrants to work in the U.S. for up to 6 years. The main objective of issuing the $\mathrm{H}-1 \mathrm{~B}$ is to fill the demand for high-skilled workers "needed" by U.S. employers due to the lack of suitable U.S. natives for such work. The J-1 visa is an exchange visitor program, which allows foreign medical graduates to practice in the U.S. for up to 7 years but be subject to two years foreign residence before applying for a permanent visa in the U.S. The restriction of foreign residency can be waived, however, if employers located in health professional shortage areas sponsor them.

5. This technique is developed in Chiswick and Miller (2005).

6. For the purpose of this study, the English-speaking countries include Canada, Ireland, Australia, New Zealand, Antigua \& Barbuda, Bahamas, Barbados, Grenada, Jamaica, St Kitts-Nevis, Dominica, St Lucia, St Vincent, Guyana, and Trinidad \& Tobago.

7. The Census enumerates all persons living on the U.S. on Census Day, including nonimmigrant workers. According to the Immigration and Naturalization Service (INS), in the year 2000, 34,527 Japanese non-immigrants were admitted to the U.S. with an intracompany transfer visa (L1 visa), compared to only 7,094 Japanese immigrants admitted under family-sponsored and employment-based visas. An intra-company transferee is defined by the INS as an alien who seeks to enter the U.S. temporarily in order to work for 
the same employer in a capacity that is primarily managerial, executive, or involves special knowledge (including science and engineering skills). 


\section{REFERENCES}

Berman, Eli, et al., 2000, "Language-Skill Complementarily: Returns to Immigrant Language Acquisition”, NBER Working Paper No.7737, National Bureau of Economic Research, Cambridge.

Betts, Julian and Loftstrom, Magnus, 1998, “The Educational Attainment of Immigrants: Trends and Implication”, NBER Working Paper No.6757, National Bureau of Economic Research, Cambridge.

Carliner, Geoffrey, 1995, “The Language Ability of U.S. Immigrants: Assimilation and Cohort Effect”, NBER Working paper No.5222, National Bureau of Economic Research, Cambridge.

Carliner, Geoffrey, 2000, “The language ability of U.S. Immigrants: Assimilation and Cohort effects”, International Migration Review, 34 (1): 158-182.

Chiswick, Barry R., 1978, "The Effect of Americanization on the Earnings of Foreign-born Men”, Journal of Political Economy, 86 (5): 827-921.

Chiswick, Barry R. and Paul W. Miller, 1992, "Language in the Labor Market: The Immigrant Experience in Canada and the United States” In Immigration, Language and Ethnic Issues: Canada and the United States, ed. Barry Chiswick, American Enterprise Institute, Washington, D.C.

Chiswick, Barry R. and Paul W. Miller, 1995, “The Endogeneity between Language and Earnings: International Analysis”, Journal of Labor Economics, 13: 246-288.

Chiswick, Barry R. and Paul W. Miller, 1998, “English Language Fluency among Immigrants in the United States”, Research in Labor Economics, 17: 151-200.

Chiswick, Barry R. and Paul W. Miller, 2005, "Linguistic Distance: A Quantitative Measure of the Distance between English and Other Languages”, Journal of Multilingual \& Multicultural Development, 26: 1-11.

Chiswick, Barry R. and Paul W. Miller, 2007, "Matching Language Proficiency to Occupation: The Effect of Immigrants’ earnings”, IZA Discussion Paper No. 2587, Institute for the Study of Labor, Bonn, Germany.

Committee on Equal Opportunities on Science and Engineering, 2003, "2000 Biennial Report to the United States Congress”, National Science Foundation, Washington.

Dustmann, Christian, 1994, "Speaking Fluency, Writing Fluency and Earnings of Migrants”, Journal of Population Economics, 7 (2): 11-56. 
Dustmann, Christian, 1999, "Temporary Migration, Human Capital and Language Fluency of Migrants”, Scandinavian Journal of Economics, 101: 297-314.

Fong, Tony, 2005, “Nurse Visa Crisis Eases,” Modern Healthcare, 35 (24): 28.

Hart-Gonzales Lucinda and Stephanie Lindemann, 1993, Expected Achievement in Speaking Proficiency, School of Language Studies, Foreign Services Institute, Department of State.

Jasso, G., et al., 2000, "The Changing Skill of New Immigrants to the United States: Recent Trends and their Determinants," in Borjas, G (ed), Issues in the Economics of Immigration, The University of Chicago Press, Chicago and London, 185-225.

Kapur, Devesh and John McHale, 2005, Give Us Your Best and Brightest: The Global Hunt for Talent and Its Impact on the Developing World, Center for Global Development, Washington, DC.

Kossoudji, Sherri, 1988, "English Language Ability and the Labor Market Opportunities of Hispanic and East Asian Immigrant Men”, Journal of Labor Economics, 6 (2): 205228.

Long, Michael, 1990, "Maturational Constraints on Language Development”, Studies in Second Language Acquisition, 12(3): 251-285.

Mariani, Matthew, 1999, "Replace with a Database: O*NET replaces the Dictionary of Occupational Titles”, Occupational Outlook Quarterly, 43(1): 2-9.

McFadden, D., K. Train and W. B. Tye, 1981, “An Application of Diagnostic Tests for the Independence from Irrelevant Alternatives Property of the Multinomial Logit Model," Transportation Research Record, 637, 39-46.

National Science Board, 2003, The Science and Engineering Workforce Realizing America's Potential, National Science Foundation, Arlington, VA.

National Science Foundation, 2006, "First-Time S\&E Graduate Enrollment of Foreign Students Drops for the Third Straight Year”, Info Brief, NSF 06-321, Arlington, VA. 


\section{TABLES}

TABLE 1. ENGLISH SPEAKING ABILITY OF MALE HIGH-SKILLED IMMIGRANTS, 2000: BY COUNTRY-OF-ORIGIN (PERCENTAGES)

\begin{tabular}{|c|c|c|c|c|c|c|}
\hline & English & Very well & Well & Not well & Not at all & Total \\
\hline ESDC & 87.7 & 10.8 & 1.1 & 0.4 & 0.0 & 100.0 \\
\hline Eastern Europe & 12.7 & 55.3 & 28.3 & 3.5 & 0.2 & 100.0 \\
\hline Other Europe & 46.0 & 46.2 & 6.9 & 0.8 & 0.1 & 100.0 \\
\hline Mexico & 11.7 & 64.1 & 15.8 & 6.0 & 2.4 & 100.0 \\
\hline Cuba & 13.7 & 68.1 & 12.9 & 4.1 & 1.2 & 100.0 \\
\hline Other America & 34.1 & 50.7 & 11.7 & 3.0 & 0.5 & 100.0 \\
\hline China & 6.5 & 57.0 & 33.2 & 3.1 & 0.3 & 100.0 \\
\hline Japan & 33.4 & 27.5 & 28.0 & 10.9 & 0.2 & 100.0 \\
\hline Korea & 11.9 & 44.6 & 31.6 & 11.6 & 0.3 & 100.0 \\
\hline Indochina & 7.6 & 55.7 & 33.8 & 2.8 & 0.1 & 100.0 \\
\hline Philippines & 16.3 & 71.2 & 11.6 & 0.8 & 0.0 & 100.0 \\
\hline South Asia & 10.3 & 80.1 & 9.1 & 0.5 & 0.0 & 100.0 \\
\hline Other Asia & 26.0 & 52.9 & 19.0 & 2.0 & 0.0 & 100.0 \\
\hline Africa & 32.1 & 62.5 & 4.9 & 0.3 & 0.1 & 100.0 \\
\hline Middle East & 18.0 & 70.5 & 10.8 & 0.6 & 0.0 & 100.0 \\
\hline Total & 28.5 & 54.2 & 14.8 & 2.3 & 0.2 & 100.0 \\
\hline
\end{tabular}

Source: 2000 U.S. Census 5\% Public Use Microdata Sample (PUMs)

Note: Row tables may not add to 100.0 due to rounding. 
TABLE 2: MEANS AND STANDARD DEVIATIONS OF VARIABLES, MALE HIGHSKILLED IMMIGRANTS, AGE 25 TO 64: 2000 U.S. CENSUS

\begin{tabular}{|c|c|c|}
\hline Variable & Mean & Standard deviation \\
\hline Age & 41.70 & 9.87 \\
\hline Age at migration & 23.05 & 11.69 \\
\hline Years of schooling & 17.37 & 1.45 \\
\hline Years since migration & 18.64 & 1.45 \\
\hline Fluent in English & 0.83 & 0.38 \\
\hline Citizen & 0.53 & 0.50 \\
\hline Married & 0.74 & 0.44 \\
\hline \multicolumn{3}{|l|}{ Country of Origin: } \\
\hline English-speaking developed countries & 0.120 & 0.33 \\
\hline Eastern Europe & 0.065 & 0.25 \\
\hline Other Europe & 0.114 & 0.32 \\
\hline Mexico & 0.030 & 0.17 \\
\hline Cuba & 0.021 & 0.14 \\
\hline Other America & 0.092 & 0.29 \\
\hline China & 0.111 & 0.31 \\
\hline Japan & 0.030 & 0.17 \\
\hline Korea & 0.036 & 0.19 \\
\hline Indochina & 0.033 & 0.18 \\
\hline Philippines & 0.052 & 0.22 \\
\hline South Asia & 0.160 & 0.37 \\
\hline Other Asia & 0.017 & 0.13 \\
\hline Africa & 0.042 & 0.20 \\
\hline Middle East & 0.077 & 0.27 \\
\hline \multicolumn{3}{|l|}{ Occupation: } \\
\hline Management & 0.25 & 0.43 \\
\hline Business & 0.10 & 0.29 \\
\hline Computer & 0.18 & 0.38 \\
\hline Engineer & 0.14 & 0.35 \\
\hline Sciences & 0.06 & 0.23 \\
\hline Social services & 0.03 & 0.16 \\
\hline Law & 0.02 & 0.14 \\
\hline Education & 0.07 & 0.26 \\
\hline Entertainment & 0.04 & 0.19 \\
\hline Healthcare & 0.12 & 0.33 \\
\hline Sample Size & & \\
\hline
\end{tabular}

Source: 2000 U.S. Census 5\% PUMS. 


\section{TABLE 3. MEANS AND STANDARD DEVIATION OF BASIC SKILLS REQUIREMENT: BY OCCUPATION ${ }^{*}$}

\begin{tabular}{lllll}
\hline Occupation & Speaking skill & Writing skill & Mathematics skill & Science skill \\
\hline Management & $4.36(0.44)$ & $4.02(0.57)$ & $3.54(0.62)$ & $1.65(0.88)$ \\
Business & $3.78(0.49)$ & $3.47(0.59)$ & $3.95(0.74)$ & $1.46(0.42)$ \\
Computer & $3.81(0.31)$ & $3.53(0.73)$ & $4.01(0.60)$ & $3.50(1.02)$ \\
Engineer & $3.60(0.39)$ & $3.70(0.41)$ & $4.53(0.42)$ & $4.31(0.60)$ \\
Sciences & $3.83(0.85)$ & $4.15(0.53)$ & $4.13(0.61)$ & $4.46(0.73)$ \\
Social services & $4.70(0.18)$ & $4.02(0.24)$ & $2.06(0.74)$ & $1.64(0.72)$ \\
Law & $4.93(0.25)$ & $4.50(0.00)$ & $2.35(0.14)$ & $1.47(0.99)$ \\
Education & $4.65(0.24)$ & $3.90(0.19)$ & $3.39(0.55)$ & $2.84(0.54)$ \\
Entertainment & $3.78(0.75)$ & $3.72(1.03)$ & $2.75(0.86)$ & $2.08(1.03)$ \\
Healthcare & $4.06(0.33)$ & $3.71(0.23)$ & $3.28(0.48)$ & $4.23(0.36)$ \\
Total & $4.02(0.56)$ & $3.77(0.61)$ & $3.69(0.83)$ & $2.93(1.42)$ \\
& & & & \\
\hline
\end{tabular}

Source: 2000 U.S. Census 5\% PUMS and the Occupational Information Network 5.1 Database.

Notes: Sample size is 55,518. Standard deviations in parentheses. The differences within the 10 broad occupations reflect skill requirements within more detailed occupational categories.

* The four basic skills are scaled from 1 to 5 , where 5 indicates that such skill is very important to perform tasks in a specified occupation. 
TABLE 4. FREQUENCY DISTRIBUTION OF HIGH-SKILLED MALE IMMIGRANTS: BY COUNTRY OF ORIGIN WITHIN MAJOR OCCUPATIONAL GROUPS (PERCENTAGES)

\begin{tabular}{lcccccccc}
\hline & ESDC & Eastern Europe & Other Europe & Mexico & Cuba & Other America & China & Japan \\
\hline Management & 15.8 & 5.1 & 14.9 & 3.2 & 2.6 & 10.1 & 8.3 & 4.7 \\
Business & 12.2 & 4.2 & 12.5 & 3.3 & 3.0 & 12.0 & 8.0 & 3.3 \\
Computer & 7.8 & 8.8 & 6.9 & 1.4 & 0.6 & 5.5 & 15.9 & 1.4 \\
Engineering & 9.2 & 7.7 & 9.0 & 2.5 & 1.7 & 7.1 & 15.1 & 2.6 \\
Sciences & 11.9 & 9.0 & 12.8 & 2.1 & 0.9 & 5.9 & 21.4 & 4.3 \\
Social services & 13.8 & 4.4 & 10.9 & 7.5 & 2.6 & 17.2 & 3.9 & 2.7 \\
Law & 17.0 & 5.1 & 19.9 & 4.2 & 6.0 & 11.7 & 6.1 & 3.7 \\
Education & 15.9 & 6.2 & 16.8 & 5.2 & 2.1 & 12.2 & 9.2 & 3.0 \\
Entertainment & 17.4 & 10.3 & 14.5 & 4.7 & 2.2 & 12.2 & 7.0 & 4.0 \\
Healthcare & 8.6 & 5.1 & 6.8 & 2.3 & 2.6 & 9.8 & 7.2 & 1.2 \\
Total & 12.0 & 6.5 & 11.4 & 2.9 & 2.1 & 9.2 & 11.1 & 3.0 \\
& & & & & & & & \\
\hline
\end{tabular}

\begin{tabular}{lrccccccc}
\hline & Korea & Indochina & Philippines & South Asia & Other Asia & Africa & Middle East & Total \\
\hline Management & 4.1 & 1.6 & 3.1 & 12.0 & 1.7 & 3.7 & 9.0 & 100 \\
Business & 3.8 & 2.6 & 8.4 & 12.7 & 1.7 & 5.8 & 6.4 & 100 \\
Computer & 2.4 & 4.6 & 3.9 & 31.5 & 1.6 & 2.8 & 4.8 & 100 \\
Architect & 2.5 & 6.7 & 5.7 & 15.2 & 2.1 & 2.9 & 10.0 & 100 \\
Sciences & 3.0 & 1.8 & 3.0 & 13.2 & 1.5 & 3.8 & 5.3 & 100 \\
Social services & 10.1 & 4.1 & 4.0 & 4.9 & 1.3 & 9.7 & 3.0 & 100 \\
Law & 4.2 & 2.5 & 3.9 & 3.6 & 0.8 & 3.9 & 7.5 & 100 \\
Education & 2.8 & 1.4 & 2.0 & 8.8 & 0.9 & 5.8 & 7.6 & 100 \\
Entertainment & 4.2 & 2.6 & 4.3 & 4.3 & 1.7 & 3.2 & 7.3 & 100 \\
Healthcare & 4.6 & 3.0 & 11.9 & 19.3 & 2.0 & 5.8 & 9.9 & 100 \\
Total & 3.6 & 3.2 & 5.2 & 16.0 & 1.7 & 4.2 & 7.7 & 100 \\
\hline
\end{tabular}

Source: 2000 U.S. Census 5\% PUMS.

Note: Row tables may not add to 100.0 due to rounding. 
TABLE 5. ESTIMATES OF LOGIT MODEL OF OCCUPATIONAL CHOICE, MALE HIGHSKILLED IMMIGRANTS, AGE 25-64, FLUENCY IN ENGLISH: 2000 U.S. CENSUS

\begin{tabular}{|c|c|c|c|c|c|c|}
\hline \multicolumn{2}{|c|}{ log (management/health) } & \multicolumn{2}{|c|}{ log (business/ health) } & $\log$ (comp/ health) & \multicolumn{2}{|c|}{$\log$ (engineer/ health) log (sciences/ health) } \\
\hline Constant & 13.213 & 14.598 & & 15.897 & 11.961 & -3.070 \\
\hline Yrs of schooling & -0.740 & -0.838 & & -0.703 & -0.648 & 0.219 \\
\hline $\begin{array}{l}\text { Years since migration } \\
\text { (YSM) }\end{array}$ & $0.002 \#$ & $-0.004 \#$ & & -0.120 & $-0.005 \#$ & -0.081 \\
\hline $\mathrm{YSM}^{2} / 100$ & 0.048 & 0.036 & & 0.108 & $0.012 \#$ & 0.144 \\
\hline Age at migration & 0.024 & 0.008 & & -0.049 & 0.007 & $-0.005 \dagger$ \\
\hline Citizen & -0.747 & -0.507 & & -0.573 & -0.249 & -0.766 \\
\hline Married & 0.261 & -0.130 & & 0.119 & 0.079 & $-0.065 \#$ \\
\hline \multirow[t]{2}{*}{ Fluent in English } & -0.100 & $-0.055 \#$ & & -0.306 & -0.443 & -0.519 \\
\hline & \multicolumn{2}{|c|}{$\log$ (social services/ health) } & \multicolumn{2}{|c|}{$\log$ (law /health) $\log$} & (education/ health) & $\log$ (entertain/ health) \\
\hline Constant & \multicolumn{2}{|c|}{7.645} & \multicolumn{2}{|c|}{-2.582} & -0.568 & 14.758 \\
\hline Yrs of schooling & \multicolumn{2}{|l|}{-0.554} & \multicolumn{2}{|c|}{0.153} & $0.014 \#$ & -0.859 \\
\hline $\begin{array}{l}\text { Years since migration } \\
\text { (YSM) }\end{array}$ & 0.035 & \multicolumn{3}{|c|}{-0.052} & 0.013 & $0.006 \#$ \\
\hline $\mathrm{YSM}^{2 /} / 100$ & 0.034 & \multicolumn{3}{|c|}{0.097} & 0.057 & 0.028 \\
\hline Age at migration & 0.047 & \multicolumn{3}{|c|}{-0.071} & 0.024 & 0.011 \\
\hline Citizen & -0.763 & \multicolumn{3}{|c|}{ - 0.126\# } & 0.860 & -1.040 \\
\hline Married & -0.539 & \multicolumn{3}{|c|}{-0.338} & 0.513 & -0.614 \\
\hline Fluent in English & -0.663 & \multicolumn{3}{|c|}{0.075} & $0.021 \#$ & -0.483 \\
\hline
\end{tabular}

Source: 2000 U.S. Census 5\% PUMS.

Notes: All coefficients are significant at the 5 percent level unless designated otherwise. \# Not significant at .10; $\dagger$ Significant at .10, but not at .05 .

Sample size is 65,104 . Pseudo $\mathrm{R}^{2}$ is 0.343 . Chi-square is 26,801.797. 
TABLE 6. ESTIMATES OF LOGIT MODEL OF OCCUPATIONAL CHOICE, MALE HIGHSKILLED IMMIGRANTS, AGE 25-64, LINGUISTIC DISTANCE: 2000 U.S. CENSUS

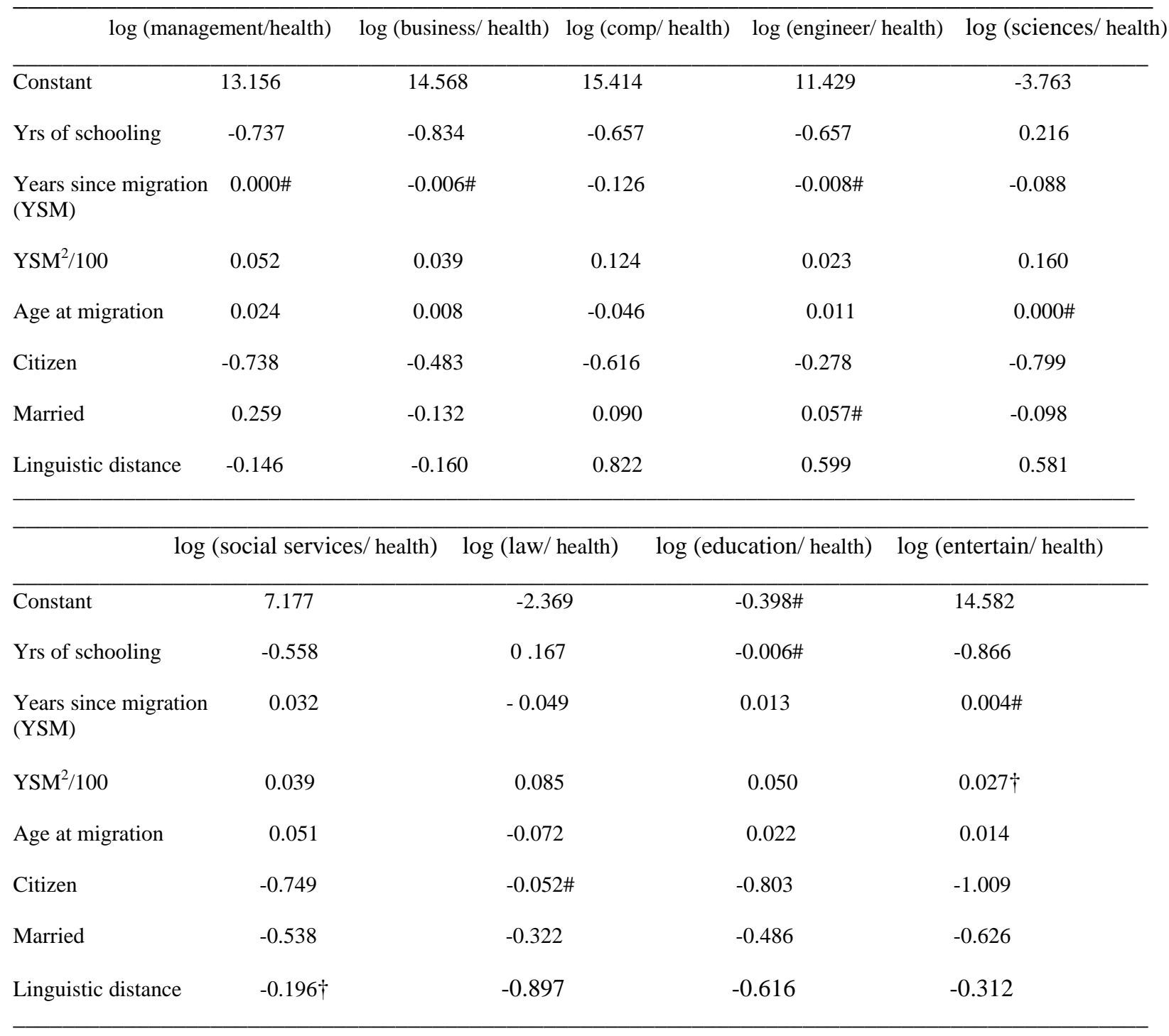

Source: 2000 U.S. Census 5\% PUMS.

Notes: All coefficients are significant at the 5 percent level unless designated otherwise. \# Not significant at .10; $\dagger$ Significant at .10, but not at .05 .

Sample size is 63,281 . Pseudo $\mathrm{R}^{2}$ is 0.326 . Chi-square is $24,472.70$. 
TABLE 7. ESTIMATES OF OLS MODEL OF OCCUPATIONAL CHOICE, MALE HIGHSKILLED IMMIGRANTS, AGE 25-64 (Dependent variable: Skills Required in Occupations, Speaking and Writing skills)

\begin{tabular}{lcc}
\hline & Speaking skill & Writing skill \\
\hline Constant & $3.165(100.715)$ & $2.889(83.609)$ \\
Years of schooling & $0.047(26.332)$ & $0.042(21.242)$ \\
Years since migration (YSM) & $0.002(2.851)$ & $0.006(7.467)$ \\
YSM ${ }^{2} / 100$ & $0.007(5.080)$ & $0.001(0.748)$ \\
Age at migration & $0.002(6.399)$ & $0.004(13.264)$ \\
Citizen & $-0.061(-9.300)$ & $-0.002(-3.076)$ \\
Married & $0.012(2.012)$ & $-0.004(-0.612)$ \\
Linguistic distance & $-0.124(-12.829)$ & $-0.121(-11.410)$ \\
Adjusted $\mathrm{R}^{2}$ & 0.028 & 0.024 \\
Sample size & & \\
\hline
\end{tabular}

Source: 2000 U.S. Census 5\% PUMS and the Occupational Information Network 5.1 Database Note: t-ratio in parentheses. 
TABLE 8. ESTIMATES OF LOGIT MODEL OF OCCUPATIONAL CHOICE, MALE HIGHSKILLED IMMIGRANTS, AGE 25-64, COUNTRY OF ORIGIN: 2000 U.S. CENSUS

\begin{tabular}{|c|c|c|c|c|c|}
\hline $\log ($ mana & agement/health) & log (business/ health) & $\log$ (comp/ health) & log (engineer/ health) & $\log$ (sciences / health) \\
\hline Constant & 14.990 & 15.861 & 17.957 & 13.402 & -1.582 \\
\hline Yrs of schooling & -0.829 & -0.904 & -0.873 & -0.762 & 0.110 \\
\hline $\begin{array}{l}\text { Years since migration } \\
\text { (YSM) }\end{array}$ & 0.0030 & 0.015 & -0.095 & 0.013 & -0.059 \\
\hline $\mathrm{YSM}^{2} / 100$ & -0.025 & $-0.010 \#$ & 0.086 & $-0.016 \#$ & 0.098 \\
\hline Age at migration & 0.027 & 0.010 & -0.039 & 0.014 & $0.001 \#$ \\
\hline Citizen & -0.534 & -0.394 & -0.640 & -0.309 & -0.742 \\
\hline Married & 0.233 & -0.160 & $-0.015 \#$ & 0.023\# & -0.124 \\
\hline Eastern Europe & -0.422 & -0.286 & 1.026 & 0.491 & 0.308 \\
\hline Other Europe & 0.473 & 0.472 & 0.406 & 0.466 & 0.445 \\
\hline Mexico & -0.506 & -0.315 & -0.720 & -0.266 & $-0.268 \dagger$ \\
\hline Cuba & -0.530 & $-0.177 \#$ & -0.764 & -0.418 & -0.852 \\
\hline Other America & -0.733 & -0.320 & -0.521 & -0.572 & -0.605 \\
\hline China & $0.088 \#$ & 0.387 & 1.657 & 1.164 & 0.914 \\
\hline Japan & 0.596 & 0.400 & -0.400 & 0.447 & 0.987 \\
\hline Korea & -0.735 & -0.547 & -0.471 & -0.747 & -0.452 \\
\hline Indochina & -1.477 & -0.874 & 0.349 & 0.393 & $-0.158 \#$ \\
\hline Philippines & -2.743 & -1.457 & -1.600 & -1.546 & -1.254 \\
\hline South Asia & -0.854 & -0.477 & 0.733 & $-0.112 \dagger$ & -0.591 \\
\hline Other Asia & -0.853 & -0.615 & $-0.153 \#$ & $-0.117 \#$ & -0.410 \\
\hline Africa & -1.074 & -0.314 & -0.536 & -0.799 & -0.623 \\
\hline Middle East & -0.513 & -0.586 & -0.192 & 0.093\# & -0.631 \\
\hline
\end{tabular}




\section{Table 8 (continued)}

\begin{tabular}{|c|c|c|c|c|}
\hline & log (social services/ health) & $\log$ (law/ health) & $\log$ (education/ health) & $\log$ (entertain/ health) \\
\hline Constant & 7.793 & -1.436 & 0.894 & 16.079 \\
\hline Yrs of schooling & -0.591 & 0.113 & -0.083 & -0.934 \\
\hline $\begin{array}{l}\text { Years since migration } \\
\text { (YSM) }\end{array}$ & 0.039 & -0.031 & 0.039 & 0.028 \\
\hline $\mathrm{YSM}^{2} / 100$ & $0.017 \#$ & 0.037 & $-0.009 \#$ & -0.041 \\
\hline Age at migration & 0.058 & -0.065 & 0.026 & 0.014 \\
\hline Citizen & -0.585 & 0.033\# & -0.677 & -0.904 \\
\hline Married & -0.508 & -0.301 & -0.477 & -0.608 \\
\hline Eastern Europe & -0.526 & -0.352 & -0.251 & 0.416 \\
\hline Other Europe & $0.050 \#$ & $-0.151 \#$ & 0.372 & 0.387 \\
\hline Mexico & 0.711 & $-0.114 \#$ & 0.285 & -0.289 \\
\hline Cuba & -0.381 & $-0.083 \#$ & -0.735 & -0.571 \\
\hline Other America & $0.095 \#$ & -0.497 & -0.303 & -0.575 \\
\hline China & -0.494 & -0.624 & $-0.094 \#$ & $0.064 \#$ \\
\hline Japan & $-0.339 \#$ & $0.467 \dagger$ & 0.350 & $0.303 \dagger$ \\
\hline Korea & 0.517 & -0.719 & -0.855 & -0.659 \\
\hline Indochina & $-0.035 \#$ & -0.910 & -1.067 & -1.003 \\
\hline Philippines & -2.096 & -1.597 & -2.488 & -2.423 \\
\hline South Asia & -1.541 & -2.082 & -1.208 & -1.806 \\
\hline Other Asia & -0.955 & -1.678 & -1.456 & -0.980 \\
\hline Africa & $0.122 \#$ & -0.822 & -0.527 & -1.258 \\
\hline Middle east & -1.362 & -0.880 & -0.694 & -0.676 \\
\hline
\end{tabular}

Source: 2000 U.S. Census 5\% PUMS.

Notes: All coefficients are significant at the 5 percent level unless designated otherwise. \# Not significant at .10; † Significant at .10, but not at .05. The reference group is immigrants from English-speaking developed countries. Sample size is 65,104 . Pseudo $\mathrm{R}^{2}$ is 0.406 . Chi-square is $33,235.01$. 


\section{APPENDIX A. OCCUPATIONAL SKILLS REQUIREMENT IN MANAGEMENT AND PROFESSIONAL OCCUPATIONS}

\begin{tabular}{|c|c|c|c|c|c|}
\hline $\begin{array}{l}\text { Census } \\
\text { Occupation } \\
\text { code }\end{array}$ & $\begin{array}{l}\text { Occupational Title } \\
\text { Management occunations }\end{array}$ & Writing & Speaking & Math & Science \\
\hline & Management occupations & & & & \\
\hline 001 & Chief executives & 4.83 & 4.83 & 4.00 & 1.33 \\
\hline 004 & Advertising and promotions managers & 3.33 & 4.16 & 2.33 & 1.00 \\
\hline 005 & Marketing and sales managers & 3.83 & 4.83 & 2.66 & 1.00 \\
\hline 010 & Administrative services managers & 4.01 & 4.00 & 3.40 & 1.72 \\
\hline 011 & Computer and information systems managers & 4.00 & 4.00 & 3.33 & 1.33 \\
\hline 012 & Financial managers & 4.16 & 4.16 & 4.66 & 1.00 \\
\hline 013 & Human resources managers & 4.40 & 4.40 & 3.60 & 1.80 \\
\hline 014 & Industrial production managers & 3.36 & 3.86 & 3.41 & 2.34 \\
\hline 015 & Purchasing managers & 3.40 & 4.20 & 3.60 & 1.20 \\
\hline 016 & Transportation, storage, and distribution managers & 3.50 & 3.83 & 3.33 & 1.16 \\
\hline 020 & Farm, ranch, and other agricultural managers & 3.00 & 3.83 & 3.66 & 3.60 \\
\hline 021 & Farmers and ranchers & 2.80 & 3.40 & 3.40 & 3.60 \\
\hline 022 & Construction managers & 3.16 & 3.50 & 3.66 & 2.33 \\
\hline 023 & Education administrators & 4.25 & 4.50 & 3.00 & 1.66 \\
\hline 030 & Engineering managers & 4.00 & 4.33 & 3.83 & 4.16 \\
\hline 031 & Food service managers & 3.16 & 3.66 & 2.83 & 1.50 \\
\hline 032 & Funeral directors & 3.00 & 4.00 & 2.33 & 1.50 \\
\hline 033 & Gaming managers & 3.40 & 4.40 & 4.00 & 1.20 \\
\hline 034 & Lodging managers & 3.00 & 4.33 & 3.00 & 1.00 \\
\hline 035 & Medical and health services managers & 4.25 & 4.38 & 3.46 & 3.08 \\
\hline 036 & Natural sciences managers & 4.16 & 4.33 & 3.66 & 4.16 \\
\hline 040 & Postmasters and mail superintendents & 3.50 & 3.83 & 3.00 & 1.16 \\
\hline 041 & Property, real estate, and community managers & 3.60 & 4.40 & 3.20 & 1.00 \\
\hline 042 & Social and community services managers & 3.60 & 4.40 & 2.40 & 1.80 \\
\hline & Business and financial operations occupations & & & & \\
\hline 050 & Agents and business managers of artists & 3.00 & 3.83 & 3.50 & 1.33 \\
\hline 051 & Purchasing agents and buyers, farm products & 3.80 & 3.80 & 3.60 & 2.20 \\
\hline 052 & Wholesale and retail buyers, except farm products & 3.57 & 4.07 & 3.70 & 1.57 \\
\hline 053 & $\begin{array}{l}\text { Purchasing agents, except wholesale, retail and farm } \\
\text { Claims, adjusters, appraisers, examiners, and }\end{array}$ & 3.50 & 3.66 & 3.66 & 1.16 \\
\hline 054 & investigators & 3.50 & 3.66 & 4.00 & 1.66 \\
\hline 056 & Compliance officers & 3.80 & 4.00 & 3.80 & 4.00 \\
\hline 060 & Cost estimators & 4.04 & 3.91 & 4.30 & 2.62 \\
\hline 062 & $\begin{array}{l}\text { Human resources, training, and labor relations } \\
\text { specialists }\end{array}$ & 3.00 & 4.33 & 2.16 & 1.50 \\
\hline 071 & Management analysts & 4.54 & 4.36 & 3.09 & 1.72 \\
\hline 080 & Accountants and auditors & 3.07 & 3.35 & 4.54 & 1.32 \\
\hline 081 & Appraisers and assessors of real estate & 3.80 & 2.20 & 3.40 & 1.00 \\
\hline 082 & Budget analysts & 3.66 & 3.50 & 4.50 & 2.00 \\
\hline 083 & Credit analysts & 4.16 & 4.50 & 4.16 & 2.16 \\
\hline 084 & Financial analysts & 3.50 & 3.66 & 4.66 & 1.16 \\
\hline 085 & Personal financial advisors & 3.40 & 4.40 & 4.00 & 1.00 \\
\hline 086 & Insurance underwriters & 3.33 & 2.83 & 3.66 & 1.50 \\
\hline
\end{tabular}




\begin{tabular}{|c|c|c|c|c|c|}
\hline $\begin{array}{l}\text { Census } \\
\text { occupation } \\
\text { code }\end{array}$ & Occupational title & Writing & Speaking & Math & Science \\
\hline 090 & Financial examiners & 4.00 & 4.20 & 3.80 & 1.40 \\
\hline 093 & Tax examiners, collectors, and revenue agents & 3.50 & 3.66 & 4.66 & 1.50 \\
\hline \multirow[t]{2}{*}{094} & Tax preparer & 2.83 & 3.50 & 4.33 & 1.50 \\
\hline & Computer and mathematical science occupations & & & & \\
\hline 101 & Computer programmers & 4.33 & 3.50 & 3.16 & 2.00 \\
\hline 102 & Computer software engineers & 2.83 & 4.00 & 4.5 & 4.33 \\
\hline 104 & Computer support specialists & 4.16 & 4.16 & 3.66 & 3.66 \\
\hline 106 & Database administrators & 3.80 & 3.40 & 4.40 & 2.00 \\
\hline 110 & Network and computer systems administrators & 4.00 & 3.00 & 3.60 & 3.00 \\
\hline 111 & Network systems and data communication analysts & 4.50 & 4.16 & 3.66 & 3.83 \\
\hline 120 & Actuaries & 3.83 & 3.33 & 5.00 & 2.50 \\
\hline 121 & Mathematicians & 3.66 & 3.33 & 5.00 & 3.00 \\
\hline 122 & Operation research analysts & 4.16 & 3.66 & 4.50 & 4.00 \\
\hline 123 & Statisticians & 4.16 & 3.50 & 5.00 & 4.16 \\
\hline \multirow[t]{2}{*}{124} & Miscellaneous mathematical science occupations & 3.33 & 3.66 & 4.66 & 3.83 \\
\hline & Architecture and engineering occupations & & & & \\
\hline 130 & Architects, except naval & 3.99 & 3.96 & 3.50 & 2.85 \\
\hline 131 & Surveyors, cartographers, and photogrammetrists & 3.16 & 2.50 & 4.83 & 3.83 \\
\hline 132 & Aerospace engineers & 4.33 & 3.83 & 5.00 & 5.00 \\
\hline 133 & Agricultural engineers & 4.16 & 4.33 & 4.83 & 5.00 \\
\hline 135 & Chemical engineers & 3.50 & 3.83 & 4.00 & 4.83 \\
\hline 136 & Civil engineers & 3.96 & 3.66 & 4.81 & 4.44 \\
\hline 140 & Computer hardware engineers & 2.83 & 4.00 & 4.50 & 4.33 \\
\hline 141 & Electrical and electronics engineers & 3.80 & 3.60 & 4.80 & 4.60 \\
\hline 143 & Industrial engineers & 4.00 & 4.00 & 4.16 & 4.50 \\
\hline 144 & Marine engineers and naval architects & 4.25 & 3.91 & 4.41 & 4.08 \\
\hline 145 & Materials engineers & 3.00 & 3.40 & 4.00 & 4.00 \\
\hline 146 & Mechanical engineers & 3.25 & 3.16 & 4.62 & 4.20 \\
\hline 150 & Mining and geographical engineers & 4.50 & 4.08 & 4.83 & 4.83 \\
\hline 151 & Nuclear engineers & 4.40 & 4.00 & 4.60 & 5.00 \\
\hline 152 & Petroleum engineers & 4.60 & 4.20 & 4.80 & 4.60 \\
\hline 154 & Drafters & 3.34 & 3.78 & 4.04 & 2.91 \\
\hline 155 & Engineering technicians & 3.20 & 2.40 & 4.60 & 5.00 \\
\hline 156 & Surveying and mapping technicians & 3.00 & 2.33 & 3.33 & 1.50 \\
\hline 160 & Agricultural and food scientists & 3.50 & 3.00 & 3.83 & 4.66 \\
\hline 161 & Biological scientists & 3.95 & 2.46 & 3.01 & 4.97 \\
\hline 164 & Conservation scientists & 3.33 & 4.16 & 4.50 & 4.66 \\
\hline 165 & Medical scientists & 4.50 & 4.66 & 4.50 & 4.83 \\
\hline 170 & Astronomers and physicists & 3.5 & 2.66 & 4.83 & 4.83 \\
\hline 171 & Atmospheric and space scientists & 4.16 & 4.50 & 4.16 & 4.50 \\
\hline 172 & Chemists and material scientists & 4.00 & 3.80 & 3.60 & 5.00 \\
\hline 174 & Environmental scientists & 3.16 & 2.50 & 4.66 & 4.50 \\
\hline 180 & Economists & 4.83 & 4.66 & 4.66 & 3.16 \\
\hline 181 & Market and survey researchers & 4.66 & 4.16 & 4.83 & 2.83 \\
\hline 182 & Psychologists & 4.80 & 4.40 & 4.40 & 4.00 \\
\hline 184 & Urban and regional planners & 4.42 & 4.22 & 2.99 & 2.12 \\
\hline 186 & Miscellaneous social scientists & 4.66 & 3.83 & 3.00 & 4.50 \\
\hline
\end{tabular}




\begin{tabular}{|c|c|c|c|c|c|}
\hline $\begin{array}{l}\text { Census } \\
\text { Occupation } \\
\text { code }\end{array}$ & Occupational title & Writing & Speaking & Math & Science \\
\hline 190 & Agricultural and food science technicians & 2.66 & 2.50 & 3.33 & 3.50 \\
\hline 191 & Biological technicians & 2.66 & 2.50 & 3.33 & 3.50 \\
\hline 192 & Chemical technicians & 3.40 & 2.80 & 3.80 & 4.40 \\
\hline 193 & Geological and petroleum technicians & 3.60 & 3.60 & 4.00 & 3.60 \\
\hline \multirow[t]{2}{*}{194} & Nuclear technicians & 3.40 & 3.00 & 3.40 & 4.20 \\
\hline & Community and social services occupations & & & & \\
\hline 200 & Counselors & 4.00 & 4.83 & 3.5 & 2.83 \\
\hline 201 & Social workers & 3.63 & 4.41 & 2.05 & 1.81 \\
\hline 202 & Miscellaneous community and social service specialists & 4.33 & 4.50 & 2.00 & 2.33 \\
\hline 204 & Clergy & 4.16 & 4.83 & 1.50 & 1.00 \\
\hline 205 & $\begin{array}{l}\text { Directors, religious activities and education } \\
\text { Legal occupations }\end{array}$ & 3.40 & 4.60 & 2.60 & 1.00 \\
\hline 210 & Lawyers & 4.50 & 5.00 & 2.33 & 1.50 \\
\hline 211 & Judges, magistrates, and other judicial workers & 4.50 & 4.66 & 2.00 & 1.16 \\
\hline 214 & $\begin{array}{l}\text { Paralegals and legal assistants } \\
\text { Education, training, and library occupations }\end{array}$ & 4.50 & 4.00 & 2.83 & 1.16 \\
\hline 230 & Kindergarten teachers & 2.66 & 4.50 & 1.66 & 1.33 \\
\hline 231 & Elementary and middle school teachers & 4.00 & 4.66 & 3.33 & 3.16 \\
\hline 232 & Secondary school teachers & 3.83 & 4.83 & 4.00 & 2.66 \\
\hline 233 & Special education teachers & 4.00 & 4.50 & 3.50 & 1.66 \\
\hline 240 & Activists, curators, and museum technicians & 3.80 & 3.40 & 2.20 & 1.40 \\
\hline 243 & Librarians & 3.33 & 4.00 & 1.66 & 1.16 \\
\hline 244 & Library technicians & 3.40 & 3.40 & 2.00 & 1.00 \\
\hline 254 & $\begin{array}{l}\text { Teacher assistants } \\
\text { Art, design, entertainment, sports, and media } \\
\text { occupations }\end{array}$ & 3.40 & 4.60 & 2.60 & 1.80 \\
\hline 260 & Artists and related workers & 3.50 & 4.07 & 3.32 & 1.79 \\
\hline 263 & Designers & 3.83 & 3.66 & 3.66 & 3.50 \\
\hline 270 & Actors & 3.00 & 4.80 & 1.40 & 1.20 \\
\hline 271 & Producers and directors & 4.00 & 4.60 & 3.40 & 1.40 \\
\hline 272 & Athletes, coaches, umpires, and related workers & 1.60 & 2.80 & 1.80 & 1.00 \\
\hline 274 & Dancers and choreographers & 1.40 & 2.60 & 1.20 & 1.20 \\
\hline 275 & Musicians, singers, and related workers & 2.66 & 3.83 & 2.33 & 1.16 \\
\hline 280 & Announcers & 3.33 & 4.66 & 1.66 & 1.16 \\
\hline 281 & New analysts, reporters and correspondents & 4.66 & 4.66 & 1.83 & 1.16 \\
\hline 282 & Public relations specialists & 4.83 & 4.83 & 2.66 & 2.50 \\
\hline 283 & Editors & 5.00 & 3.40 & 2.40 & 1.40 \\
\hline 284 & Technical writers & 5.00 & 4.50 & 2.16 & 1.16 \\
\hline 285 & Writers and authors & 5.00 & 2.00 & 1.40 & 1.20 \\
\hline 286 & Miscellaneous media and communication workers & 4.50 & 4.83 & 1.16 & 1.00 \\
\hline \multirow[t]{2}{*}{291} & Photographers & 1.50 & 2.66 & 2.33 & 2.50 \\
\hline & Healthcare practitioner and technical occupations & & & & \\
\hline 300 & Chiropractors & 3.66 & 4.66 & 2.83 & 4.33 \\
\hline 301 & Dentists & 3.05 & 3.27 & 3.11 & 3.94 \\
\hline 303 & Dietitians & 3.93 & 3.99 & 2.99 & 3.60 \\
\hline 304 & Optometrists & 3.57 & 4.24 & 4.08 & 4.46 \\
\hline 305 & Pharmacists & 3.66 & 3.50 & 4.33 & 4.50 \\
\hline
\end{tabular}




$\begin{array}{clrrrr}\begin{array}{c}\text { Census } \\ \text { occupa- } \\ \text { tion code }\end{array} & \text { Occupational title } & \text { Writing } & \text { Speaking } & \text { Math } & \text { Science } \\ 306 & \text { Surgeons } & 3.80 & 4.20 & 3.40 & 4.40 \\ 311 & \text { Physician assistants } & 3.66 & 4.16 & 3.50 & 4.00 \\ 312 & \text { Podiatrists } & 3.83 & 4.66 & 2.83 & 3.50 \\ 313 & \text { Registered nurses } & 3.58 & 4.16 & 2.16 & 3.58 \\ 314 & \text { Audiologists } & 4.33 & 4.50 & 3.00 & 3.66 \\ 315 & \text { Occupational therapists } & 4.58 & 4.49 & 2.45 & 3.89 \\ 316 & \text { Physical therapists } & 3.88 & 4.35 & 2.30 & 4.07 \\ 320 & \text { Radiation therapists } & 3.80 & 3.60 & 3.00 & 4.00 \\ 321 & \text { Recreational therapists } & 4.19 & 4.12 & 1.80 & 1.53 \\ 322 & \text { Respiratory therapists } & 3.56 & 3.90 & 3.44 & 3.47 \\ 323 & \text { Speech-language pathologists } & 4.33 & 4.50 & 3.00 & 3.66 \\ 325 & \text { Veterinarians } & 4.00 & 4.50 & 3.33 & 5.00 \\ 330 & \text { Clinical lab technologists } & 3.58 & 3.50 & 2.91 & 4.33 \\ 331 & \text { Dental hygienists } & 3.70 & 4.31 & 2.08 & 3.41 \\ 332 & \text { Diagnostic related technologists } & 3.50 & 3.66 & 3.66 & 4.00 \\ 340 & \text { Emergency medical technicians } & 3.74 & 4.07 & 3.33 & 2.70 \\ 341 & \text { Health diagnosing and treating practitioners } & 4.16 & 4.50 & 3.66 & 3.16 \\ 350 & \text { Licensed practical and licensed vocational nurses } & 4.67 & 4.53 & 3.98 & 4.00 \\ 351 & \text { Medical records and health info technicians } & 3.81 & 3.85 & 2.46 & 2.02 \\ 352 & \text { Opticians } & 2.83 & 3.16 & 3.33 & 3.00\end{array}$

Source: Occupational Network 5.1 Database.

Note: * The four occupational characteristic skills are scored from 1 to 5 , where 5 indicates that such a skill is very important to perform job duties in a specified occupation. 


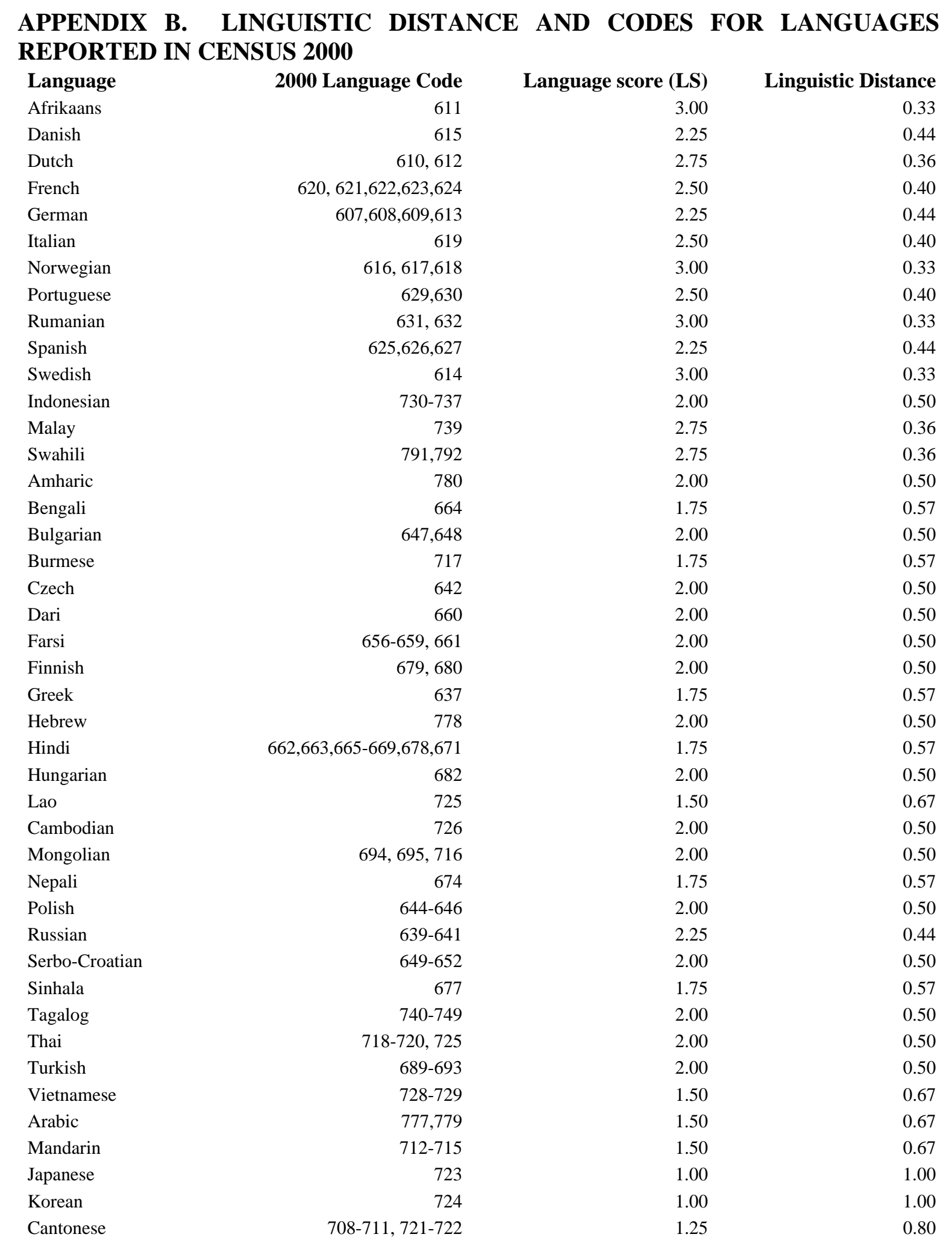

Source: Chiswick and Miller (2005)

Note:(1) The linguistic scores are based on the report by Hart-Gonzalez and Lindermann (1993).

(2) Linguistic distance is measured as an inverse of the linguistic score, 1/LS. 
